
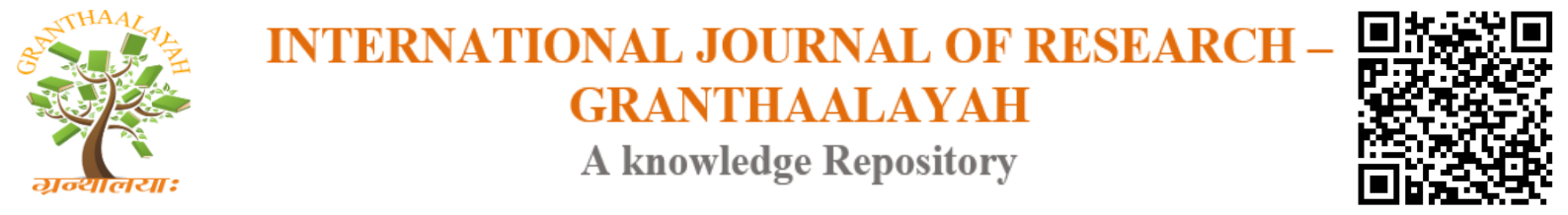

Arts

\title{
THE DIGITAL COMIC DEVELOPMENT IN INDONESIA (A CASE STUDY ABOUT THE STORY OF "SI PITUNG")
}

\author{
Menul T Riyanti ${ }^{* 1}$, Dodi Setianto ${ }^{2}$ \\ ${ }^{* 1} \mathrm{MPd}$, the Faculty of Art and Design of Trisakti University, West Jakarta, Indonesia \\ ${ }^{2}$ Lecturer of DKV Study Program, Trisakti University, West Jakarta, Indonesia
}

\begin{abstract}
Indonesia is an archipelago. It is one of the biggest archipelagos in the world. Indonesia it is 14th. Indonesia is devided by territories and each territory has its own culture. Indonesia has 245. 000.000 people as the inhabitant. The capital city of Indonesia is Jakarta and the original culture of Jakarta is Betawi. Betawi as the original culture of Jakarta has a lot of stories and one of the popular stories is "Si Pitung". The story of "Si Pitung" is being told very often by Indonesian community and becomes a legend and an inheritance from Betawi or Indonesia. Si Pitung" sometimes is beingtold as a ballad, a poem or a folk thetare. Koesasi(1992), "Si Pitung" is identified as a prominent figure from Betawi who is very humble. He is a Muslim. He is very patient and he likes to help people. He is also a person who works very hard. He is a model of social justice. Based on the folktale from Betawi culture, the authors would like to introduce the story of "Si Pitung" to be well known by people from other cities in Indonesia. The authors also hope that children and teenagers from Indonesia know the story of "Si Pitung" as he is one of the hero in Indonesia. The digital comic of "Si Pitung" can be downloaded through electronic media such as mobile phone, PC Tablet or other gadgets easily.
\end{abstract}

Keywords: Digital Comic; Traditional Story; Si Pitung; Indonesia; Main Characters.

Cite This Article: Menul T Riyanti, and Dodi Setianto. (2018). "THE DIGITAL COMIC DEVELOPMENT IN INDONESIA (A CASE STUDY ABOUT THE STORY OF "SI PITUNG")." International Journal of Research - Granthaalayah, 6(1), 107-117. https://doi.org/10.29121/granthaalayah.v6.i1.2018.1599.

\section{Introduction}

Indonesia is an archipelago. It is one of the biggest archipelagos in the world. Indonesia is the 14th. Indonesia is devided by territories and each territory has its own culture. Indonesia has 245. 000.000 people as the inhabitant. The capital city of Indonesia is Jakarta and the original culture of Jakarta is Betawi. Daerah Khusus Ibu Kota Jakarta (DKI Jakarta, Jakarta Raya) it is the only city in Indonesia that is also a province. Jakarta is located in the northwest of the Java Island. Long time ago it was known as Sunda Kelapa (before 1527), Jayakarta (1527-1619), Batavia/Batauia, or Jaccatra (1619-1942), and Djakarta (1942-1972).Jakarta has 661, $52 \mathrm{~km}^{2}$ area with $6.977,5 \mathrm{~km}^{2}$ island. In 2010 Jakarta had 9.607.787 inhabitant. 
Indigenous culture of Jakarta itself is Betawi culture. Betawi tribe is a tribe in Indonesia whose inhabitants generally reside in Jakarta. Some argue that the Betawi tribe is derived from interethnic and inter-mawin marriages in the past. Biologically, those who claim to be Betawi people are descendants of bloody mix of various tribes and nations imported by the Dutch to Batavia. The so-called Betawi people or tribes actually counted newcomers in Jakarta. This ethnic group was born from a combination of various other ethnic groups who already live in Jakarta, such as Sundanese, Javanese, Arabic, Balinese, Bugis, Makassar, Ambon, Malay and Chinese.

Indigenous Betawi people own their folklore, which among other Sipolk folklore. Basically there are three versions spread in the community about the Pitung version of Indonesia, the Netherlands, and China. Each version of the story has a different version of the story of the Pitung itself. Is Si Pitung a hero based on the Indonesian version of the story, and as a villain when viewed from the Dutch version. The story of Pitung is spoken by the people of Indonesia to date and become part of lengenda and Betawi cultural heritage in particular and Indonesia generally. The story of Si Pitung is sometimes spoken to be lantern (a kind of ballad), sair, or Lenong story. According to the Koesasi (1992) version, Si Pitung is identified with the brave Betawi figures, devout Muslims, compassionate, hardworking and helpful to be examples of a social justice. Based on the folklore of Betawi culture, the writer wants to try to raise the story of Si Pitung to be better known by all national circles nationally, especially for children and adolescents because Si Pitung itself is one of the national heroes of the State of Indonesia.

The cinematic comic tells the story of the pitung, because this cinematic comic can be accessed through electronic media in the form of, mobile phone, tablet PC and other gadgets, so that children and adults can access it more quickly and easily. the intended target is the general public especially internet users and telephones that can surf. Besides this cinematic comicity keunggulann this is a digitic comics that can reduce the use of paper media on the use of real comics. Because with the use of a little paper the author helps reduce the impact of global warming. As well as the ultimate aim is to awaken the Indonesian public about a national identity that we may not have been seized for. And making insane critical of the current situation and managing our traditions.

\section{Literature Review}

Culture deals with the way people live. Humans learn to think, feel, trust and work out what is culturally appropriate. Language, friendship, eating habits, communication practices, social actions, economic and political activities, and technology, all based on cultural patterns. Culture is an intriguing concept. Formally culture is defined as the order of knowledge, experience, belief, value, attitude, meaning, hierarchy, religion, time, role, spatial relations, the concept of the universe, material objects and possessions gained by a large group of people from generation to generation through effort individuals and groups.

\subsection{Communication Theory}

Communication is the transmission and reception of news or information between two or more persons so that the intended message can be understood; relationship; contacts Communications has been largely defined as a way to transmit information, exchange ideas, or processes to 
establish commonalities of thought between message senders and recipients. The statement is reinforced by George E. Belch and Michael A. Belch (Belch \& Belch, 2004), for communication to occur, there must be a commonality of mind between the sender of the message and the recipient of the message and the information must be sent from one person to another (or one group to another).

Communication is the transmission and reception of news or information between two or more persons so that the intended message can be understood; relationship; contacts Communications has been largely defined as a way to transmit information, exchange ideas, or processes to establish commonalities of thought between message senders and recipients. The statement is reinforced by George E. Belch and Michael A. Belch (Belch \& Belch, 2004), for communication to occur, there must be a commonality of mind between the sender of the message and the recipient of the message and the information must be sent from one person to another (or one group to another).

\subsection{Animation Theory}

Animation is a shaped picture of a set of objects (drawings) arranged regularly following the flow of movement that has been determined at every increase in the count of time that occurred. The picture or object referred to in the above definition may be a human, animal, or writing image. In the process of making the animation maker or better known as the animator must use the logic of thinking to determine the flow of motion of an object from the initial state to the final state of the object. Mature planning in the formulation of the flow of motion based on the right logic will produce an interesting animation to watch. Animation is also a technique of displaying sequential images in such a way that the audience feels the illusion of motion (motion) in the displayed image. In general, the illusion of movement is a change that is visually detected by the spectator's eye so that it does not have to be a change in position as a meaning of the term 'movement'. Changes such as color changes can be said an animation.

In the field of visual modeling graphics can be categorized as two groups namely geometric modeling and appearance modeling (appearance). Geometric modeling is a representation of the shape of the object to be displayed while the appearance modeling makes a representation of visual properties or the appearance of the object. Examples of visual properties include color and texture. Based on the definition of animation above that an animation is composed by a set of images displayed sequentially then the animation can be said a function against time. Images can be defined as a collection of geometric and visual descriptions or can be imagery. In the figure which is a collection of descriptions, the animation is defined as a function that maps the time to the parameter changes of the description. In the image that is the image, the animation is defined as a function that maps the time to each element of the image.

\subsection{Comic Theory}

Comic is a world of speech-pictures, a series of drawings that tell a story. A comic is not a picture story as we know it. In Cergam (pictorial story) the picture is acting as an illustration of the complementary text so that without the presence of cwrita images can be enjoyed by readers. In the comics that occur is the opposite text or writing role as a complement to the picture such 
as giving dialogue, narration and so be more precise comics is a gammcer or picture that tells the story that sophisticated jazz drawer can be without words.

According to Toni Masdiono in the book '14 Kick Making Comics', Comic also has anatomical form of element / comic element mentioned with certain terms. But the elements / elements of anatomy can be developed or even reduced in accordance with the improvisation of each comic artist. In this book are some of the anatomical terms of a comic.

According to Toni Masdiono in the book '14 comic-making stance ', the comic strips of comic strip panels can vary, can be thin, thick, expressive, etc.For example, the panel that uses a thin line is a standard panel and a thick striped panel can be used to accentuate something important. To describe an exciting scene, it can be described with an expressive panel line.

Regarding the Panel, there is one thing to note, namely the flow of reading. The Indonesian comic strip is read from left to right as well as the American comic strip. As for the Japanese comic story plot is read from the opposite direction, ie right to left. According to Scott McCloud, in his book Making Comics, the easiest way to avoid confusion in panel reading to panels is to make it simple. But if the author wants to use a variety of panel forms, avoid confusing arrangements. There is a way to guide the reader's eye in the right direction, by generating a spatial arrangement, composition, and motion in a frame that explains the story so as to help guide the reader's eye into the storyline.

\section{Discussion}

In Indonesia, the embryo of comics is heavily influenced by Buddhism, Hinduism, and Islam. One of the indicators can be found in Leang-leng Goa in South Sulawesi. There is a picture of a boar that could indicate the existence of a pattern of communication through the image for the community at that time. In Borobudur and Prambanan temples there are also reliefs that tell the spiritual life and culture of our society in the middle ages. The appearance of the images on the temples can also be used as a reference to the emergence of comic indonesia.Citra pictorial first appeared in Indonesia in line with the emergence of mass media in Chinese Malay during the Dutch occupation. The picture titled "Put On" by Kho Wan Gie in 1930 on the daily "Sin Po" was one of the first comics in Indonesia and became the pioneer of humor comics in the country. "Put On" tells the story of a middle-aged man who lives with his mother and two younger siblings. "Put on" is a type of cartoon story and a very popular type of humor at that time. For Indonesian comic artists, a realistic illustrated picture begins with the emergence of a comic book titled "Mentjari Poetri Hidjau" by Nasoen As in 1939. The picture story it was published in Ratoe Timore magazine on February 1, 1939. "The teachings of Poetri Hidjau" is a fantasy story unearthed from the Sumatran folklore. In terms of narrative, arguably this is the first Indonesian comic that the format is complete as a modern comic. If "Put On" is a comic strip category (the story is fragmentary), the comic "Mentjari Poetri Hidjau" at that time can be booked.

In 1953, Indonesian comics entered the beginning of the golden age with the publication of comics titled "Sri Asih" by R.A. Kosasih and the comic "Nina Putri Rimba" by Johnlo who appeared simultaneously. Sri Asih is a superhero character who was adopted from the comic "Wonder Woman". While Nina is a Tarzan female figure. The comic "Sri Asih" is often regarded 
as an early milestone in the development of comic book shaped in Indonesia, so R.A. Kosasih didapuk as "Father of Indonesian Comics". Name R.A. Kosasih also shines after he is considered a comic artist who managed to bring the Mahabharata epic from wayang into comic book media. The history of Indonesian comics went through a tricky period in 1963-1965. At that time, Indonesian comics brought more messages of Old Order political propaganda. The contents of the comic at that time much to tell about the struggle against neocolonialism, rebellion, and ideology. While at the end of 1965, when the state was stable, popular comics were no longer told as they were written, but it was about teenage romance highlighting the story of a metropolitan teenager. The golden age and the rise of both Indonesian comics took place in 1980. It was marked by the many variations and comic titles that emerged. The popular comics of the time were comic-themed adventures of martial arts warriors and superheroes, such as the Blind from the Ghost Cave, the White Wolf Demon, the Kedaung Landlord, the Djampang, the Skull Banner, the Godam, the Gundala and others. Indonesian children and adolescents are more familiar with comics by Japanese artists than by domestic comic artists. They love Japanese comics because the quality of the story and the format is very interesting, can even beat Walt Disney's American-style comics on the market. The shops and bookshops are filled with imported images from the Land of the Rising Sun.

\section{Results of Final Work Comic Digital \\ Title Si Pitung \\ By Nico Sandjaya}

Story Board Comik Si Pitung

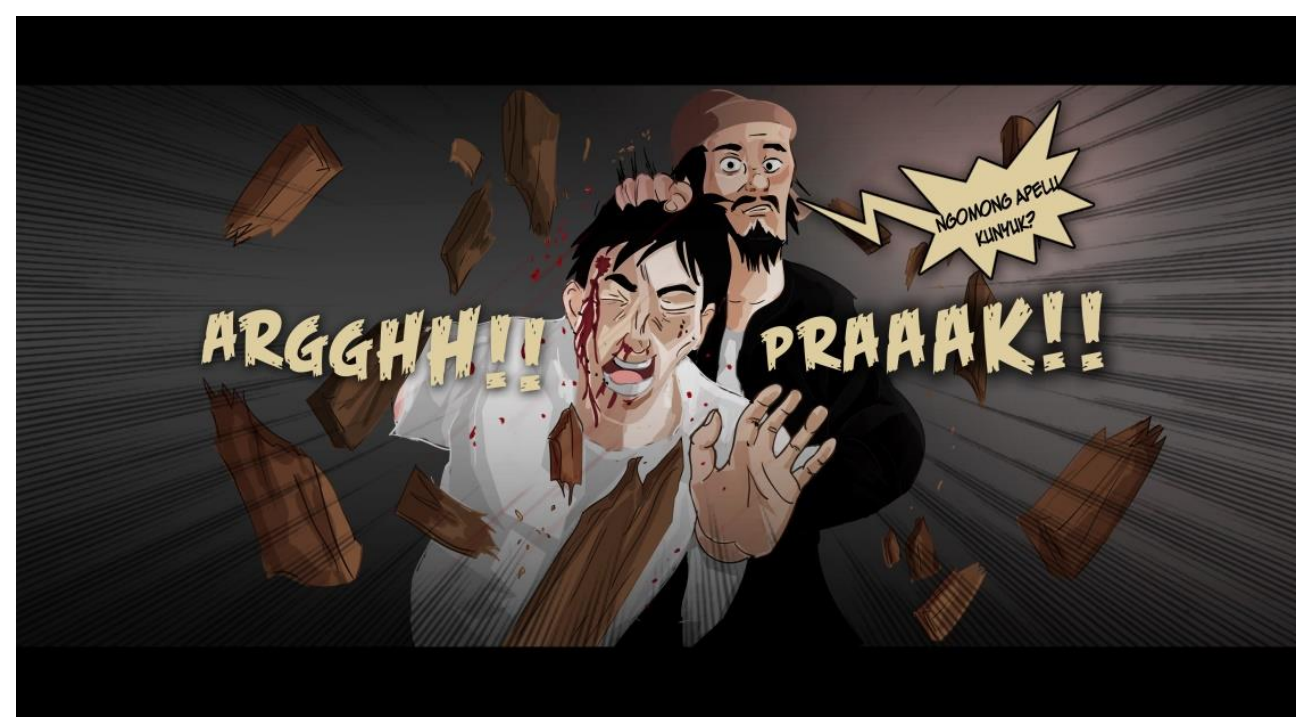

Figure 3.1: Fighting scenes Ilustration byNico Sandjaya

Illustration In a fight with the martial arts of pencak silat, the characters or mimic in the illustration with the head restrained with the blood tetesa. Sentences that are made very precise by adding a sentence that menyatak kesaikitan. Plus the effect of the image that gives the impression looks i pitung a hero 


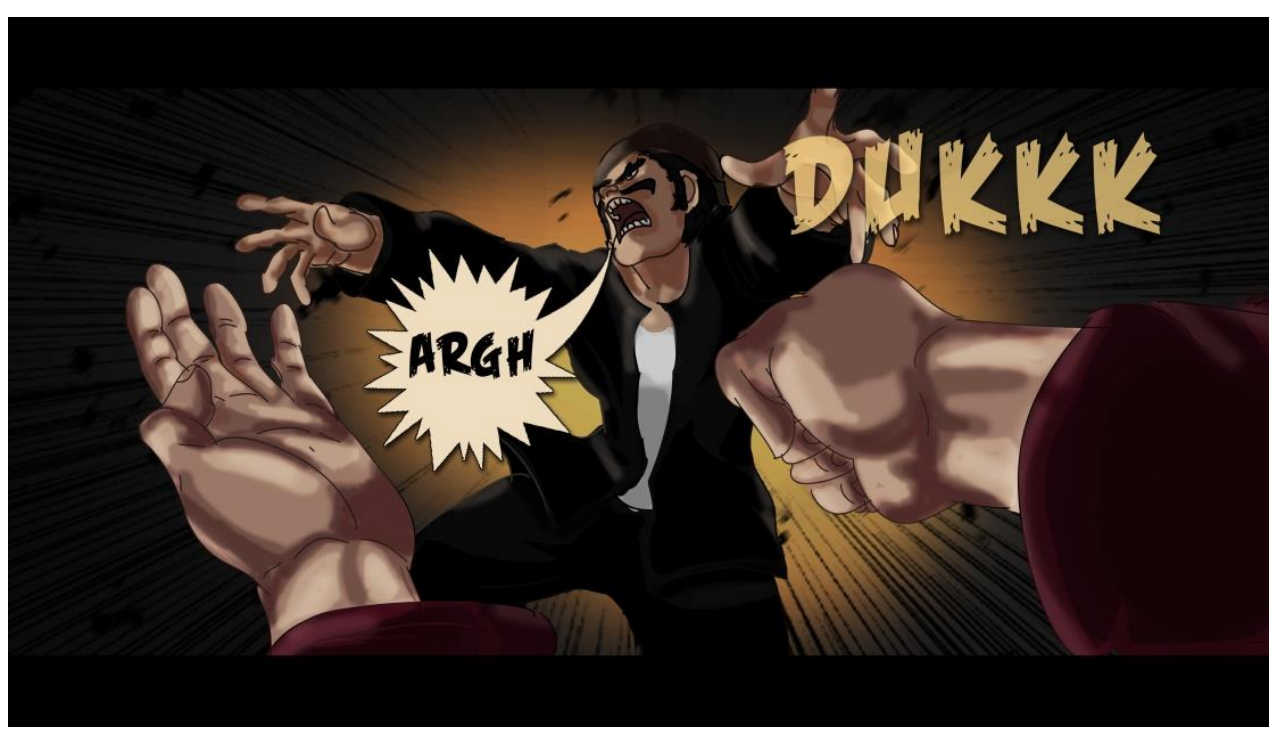

Figure 3.2: Rescue Si Pitung fight with a mask Ilustration byNico Sandjaya

Illustrations in the illustrations can be seen clearly the character of the Pitung as a champion or whiz with just memperliatkan fist picture so sturdy that drawings that Si Pitung is a knight always defend the society cannot afford. Detailed hand drawings and then mimic the character of the villain has a very perfect whiz.

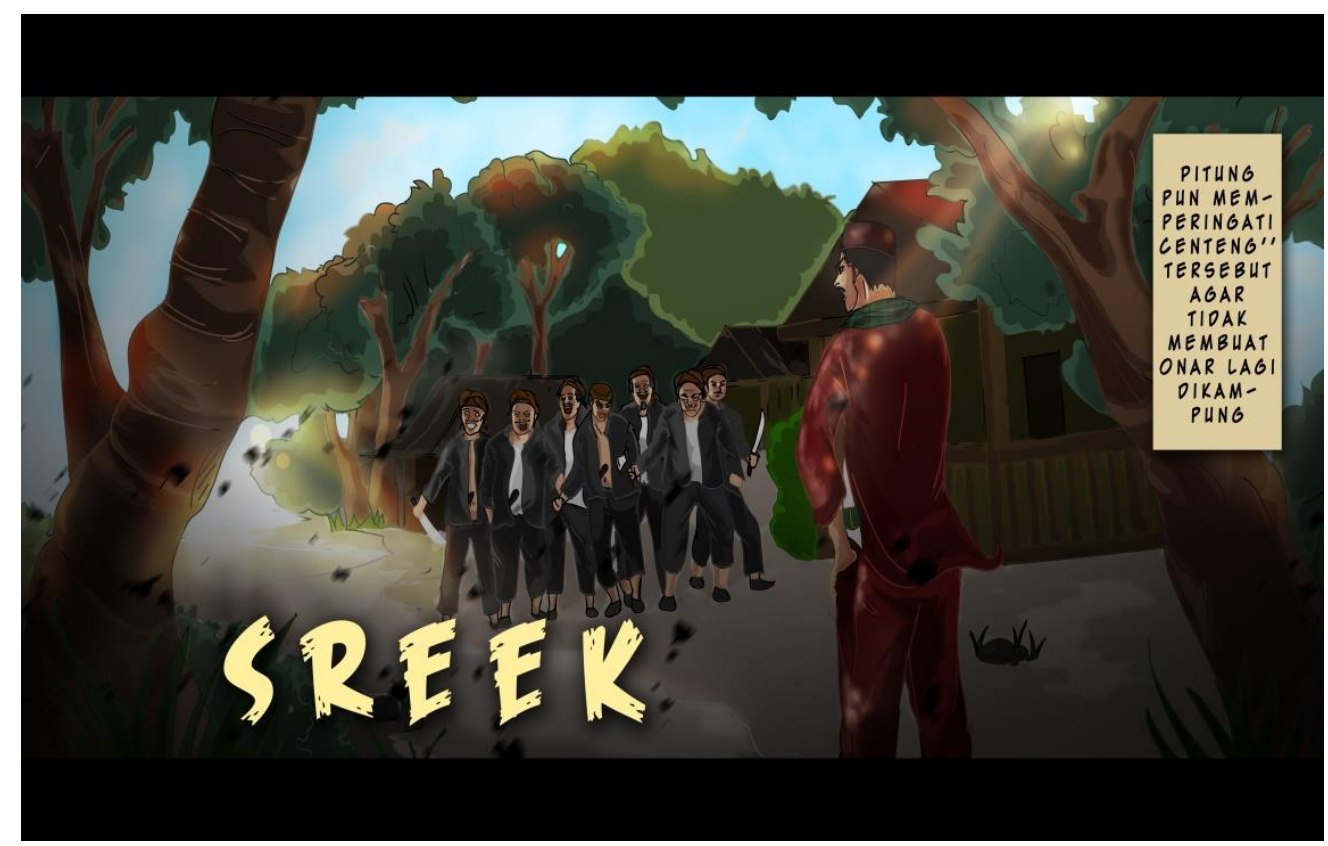

Figure 3.2: Rescue Si Pitung fight with a mask Ilustration byNico Sandjaya 


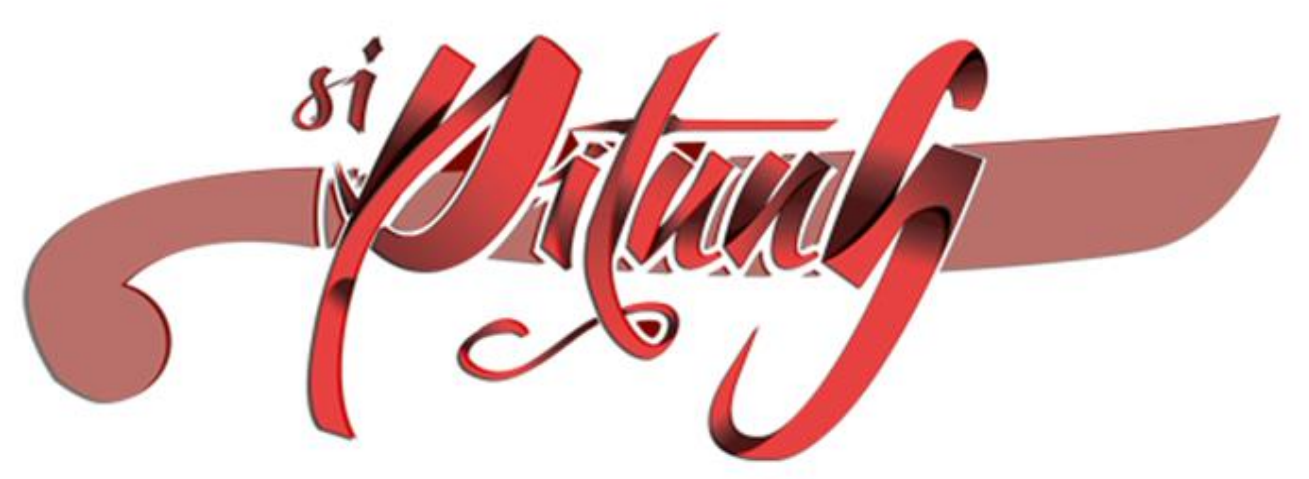

Figure 3.3: Logo from Si Pitung Ilustration byNico Sandjaya

The logo of the pitung in this digital comic focuses comic concept focused on the age of the students, whose purpose is to invite the students to watch the comics made by the children of their own country. On the basis of the segmentation, the author makes a slightly interesting logotype. The font is designed like handwriting and red colored. The red color here symbolized by one of the bold Pitung's character, red font and color is also designed to get the impression of exclusive and elegant because it is shown for the age of over 15 years. To add to the masculine impression of the figure of Pitung.

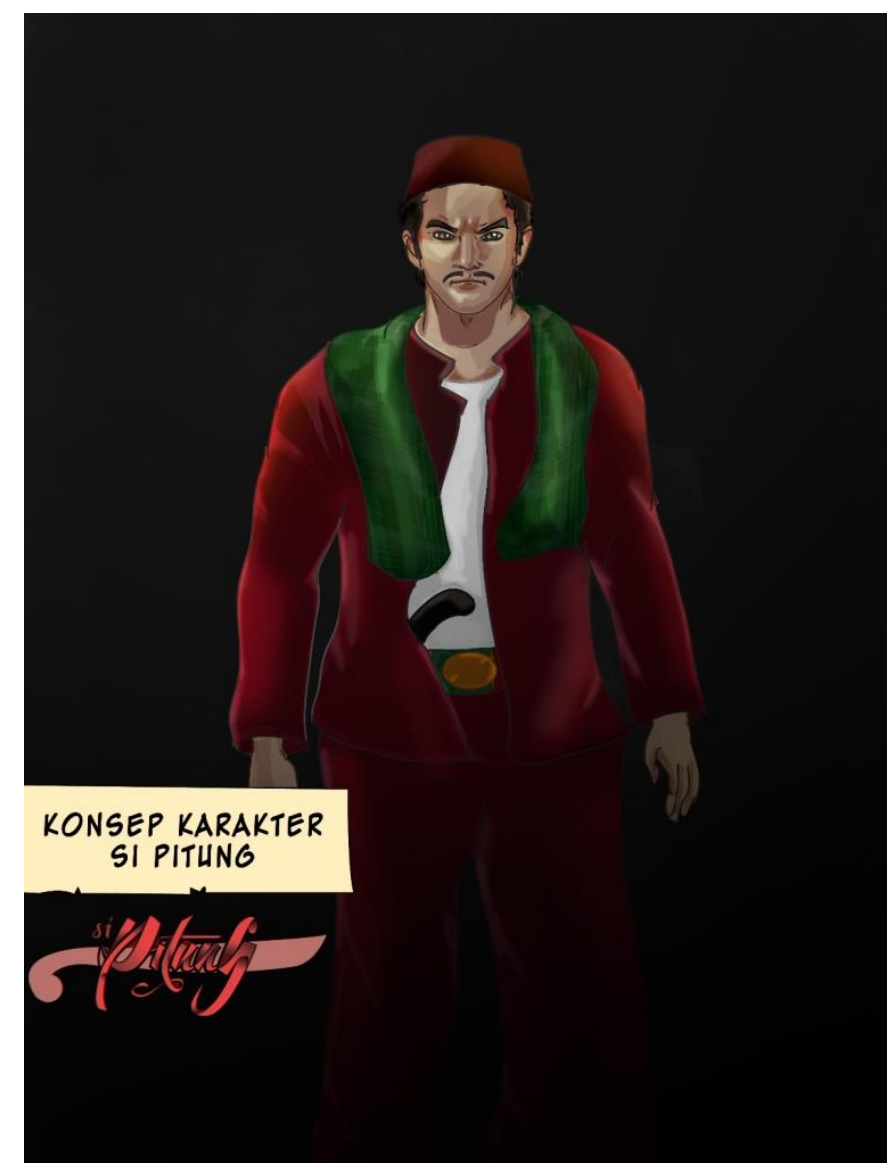

Figure 3.5: character of the Pitung Ilustration byNico Sandjaya 
The characters of the old-time betawi heroes are identical to brightly colored clothes like red and green. The Betawi people tend to be diligent and obedient to their religion. Therefore, usually every day they want to travel, they always carry a sarong, to run the activities of prayer. In addition, their pants using $3 / 4$ size is intended so that their pants are not dirty which will result in the unauthorized conduct of their prayers. For the character of the body and face of the Pitung, a sturdy body with whiskers and whiskers. A typical Betawi cloth wears a black cap, a large green belt then added with a dagger for self-defense if it is an emergency.

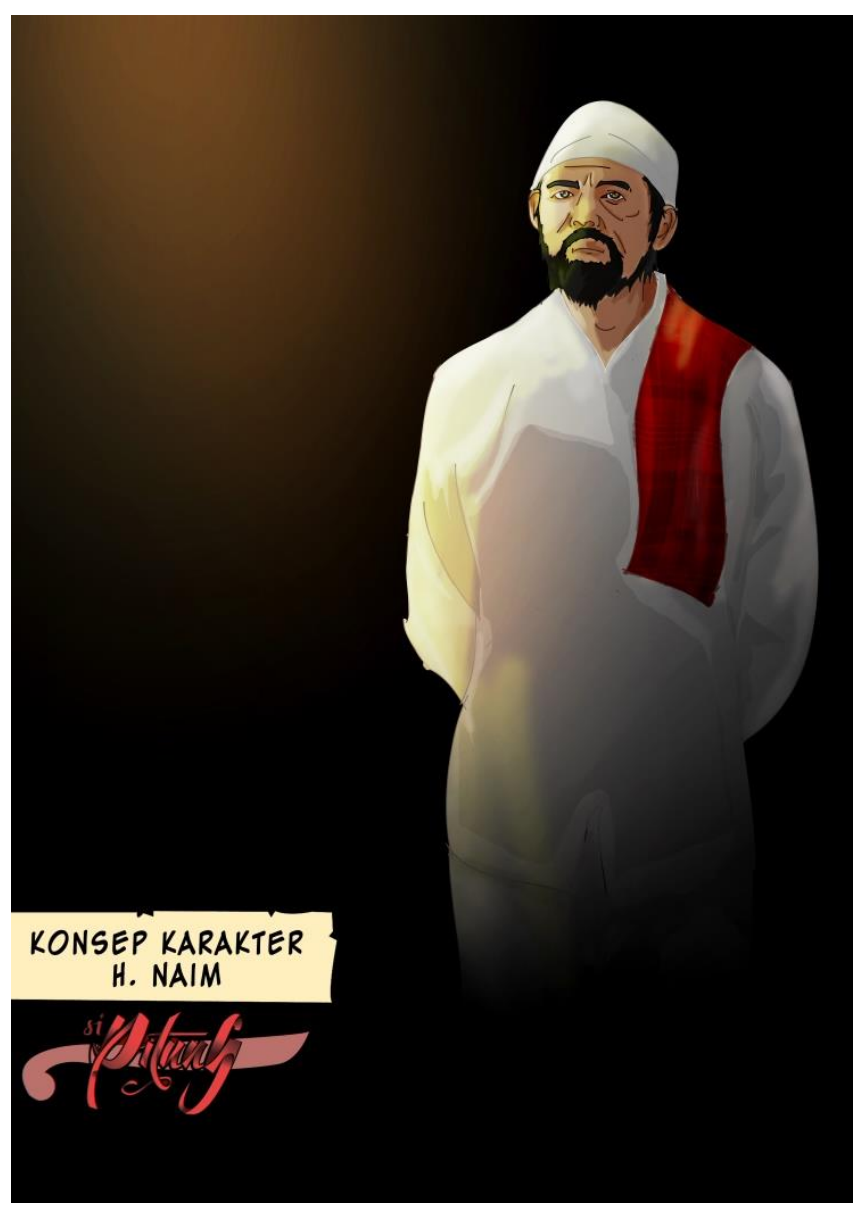

Figure 3.5: character of H Naim Ilustration byNico Sandjaya

Si Pitung has martial arts skills from H. naipin which is none other than its own enkong. In the land of Betawi itself, a religious leader and martial artist is highly respected by the inhabitants. They believe that religious leaders and martial arts have unusual knowledge that is explained scientifically. They usually use very Islamic dress suits, such as koko and turban, and they usually maintain a beard in accordance with the sunna Rassullah. The character with the age stature of the twilight but not too old anyway. 


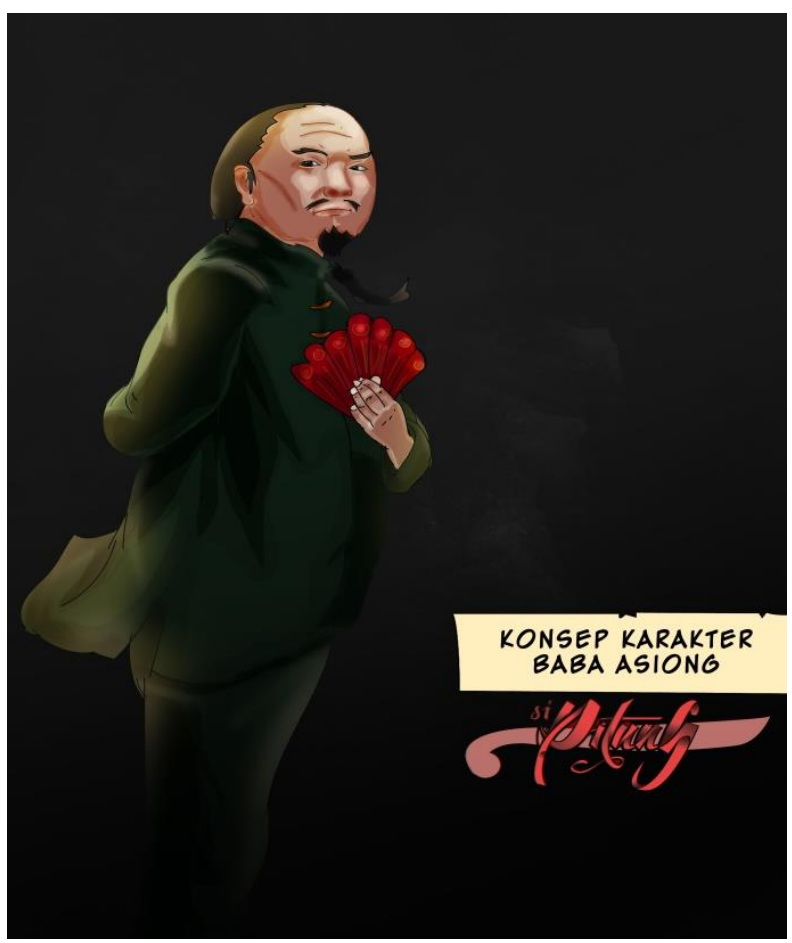

Figure 3.6: character of Baba Asiong Ilustration byNico Sandjaya

Baba Asiong is a good Chinese descendant in business portrayed with an antagonist character he is a landlord who likes to rent and buy citizens' land using terror threats if the inhabitants do not provide very cheap prices on sale at very expensive prices. To smooth his evil plans, Baba Asiong has employed many champions from his own land of betawi to become cement-centered cuds to the poor. Baba Asiong is the enemy of Si Pitung because of his very greedy nature illustrated with a flat face with a ruthless stare then with a fan in the hands of cursing red,

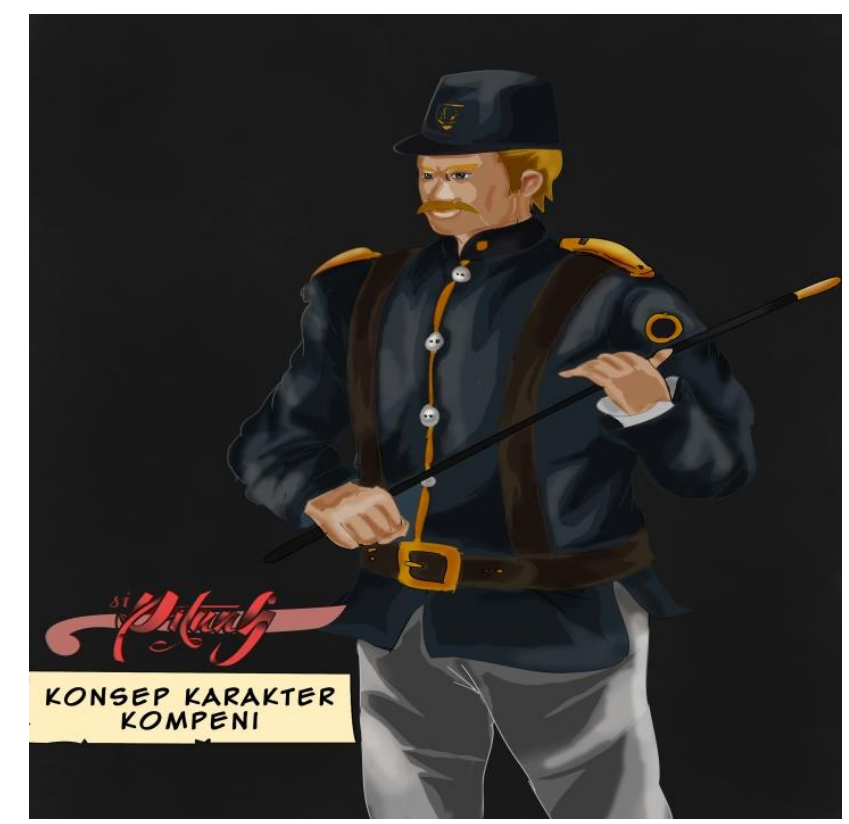

Figure 3.7: character of Kompenillustration byNico Sandjaya 
Betawi or at that time named Batavia is one place of Dutch colonial government. Therefore all regulations, systems of government and others are governed by the Dutch government. The Dutch government imposed forced labor on indigenous people including 'down rats'. In this movement the people are mobilized to eradicate rats in the fields besides dozens of other forced labor. Not to mention the blasting (tax) that is very burdensome farmers by the landlords. The taxpayers 'scholars' character named Schout Van Hinne, who is Schout (the equivalent of the Police Chief) assigned by the center to arrest Pitung and his followers, has data showing that Schout Van Hinne is a fact figure assigned to capture Pitung.

The character depicted in a typical Dutch royal army dress is pinned for gray trousers plus commando stick and ruthless and cruel expression.

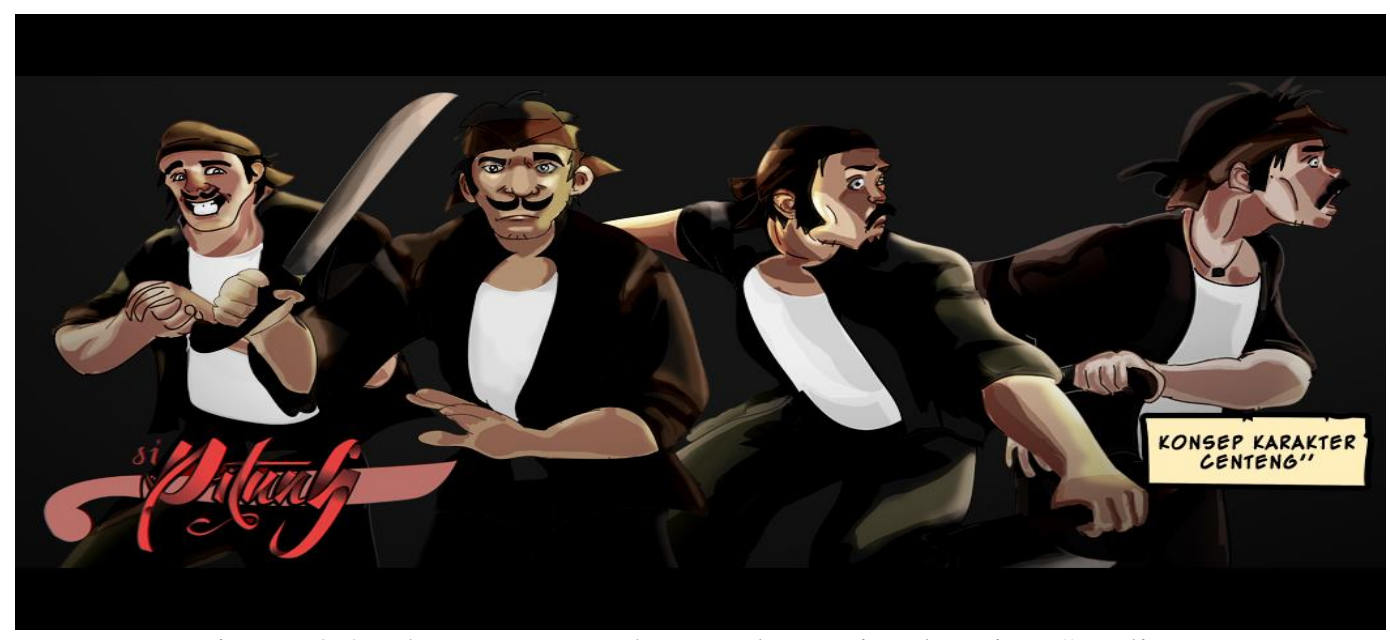

Figure 3.8: character Dutch port Ilustration byNico Sandjaya

The other antagonists are the centengs. Actually the centeng-centeng is a champion-martial arts master with great ability. The jawara were usually hired at high prices by the landlords or by the Dutch government. The inhabitants also believe that the champions possess immune sciences and so on, so it is feared by the inhabitants. They are identical with black-colored outfits, with ghostly looks, even bias and expert and use sharp weapons like machetes, axes.

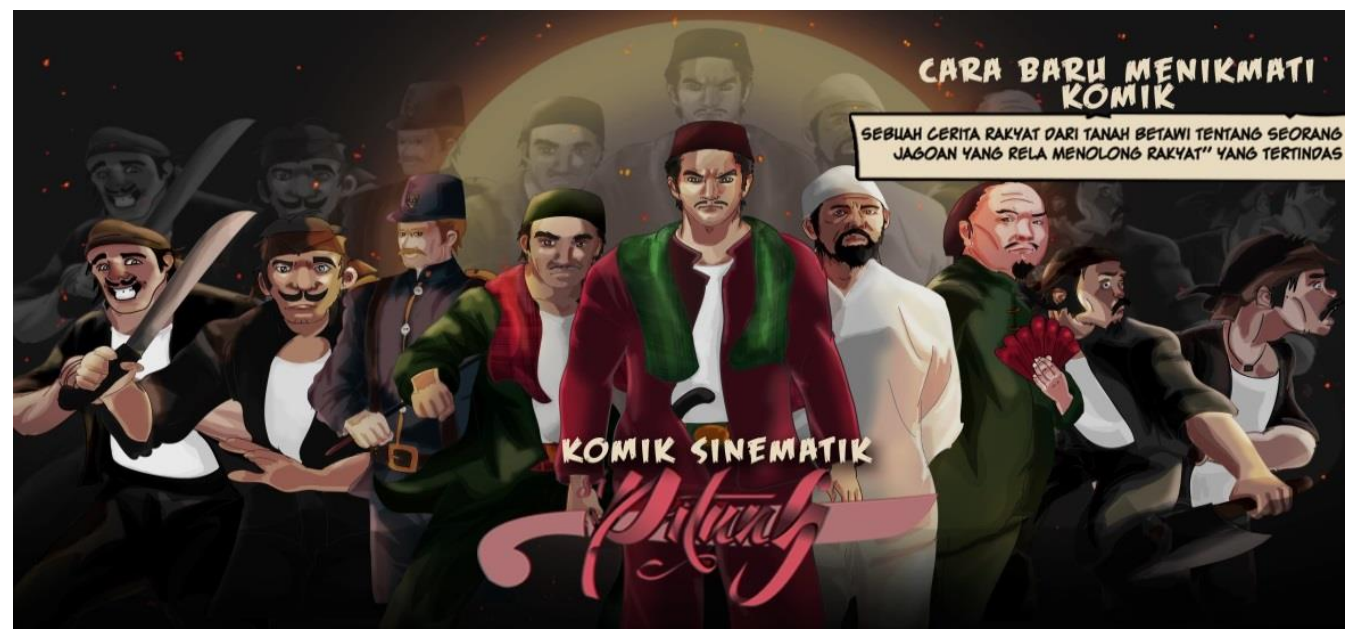

Figure 3.8: character Dutch portIlustration byNico Sandjaya 
The other antagonists are the name of Betawi centengs. Actually the centeng is a championmartial arts master with great ability. The jawara were usually hired at high prices by the landlords or by the Dutch government. The inhabitants also believe that the champions possess immune sciences and so on, so it is feared by the inhabitants. They are identical with blackcolored outfits, with ghostly looks, even bias and expert and use sharp weapons like machetes, axes.

\section{References}

[1] Sachari, Agus, pengantar Metode Penelitian Budaya Rupa dan Desain (Arsitektur, Seni Rupa, dan Kriya), Jakarta, penerbit Erlangga, 2005

[2] Rakhmat, Jalaluddin, Psikologi Komunikasi, Penerbit PT. Remaja Rosdakarya, Bandung, 2001.

[3] 3. Shimp, Terence, Periklanan dan Promosi Aspek Tambahan Komunikasi Pemasaran Terpadu, Jakarta, penerbit Erlangga, 2003.

[4] Sihombing, Danton, Tipografi dalam Desain Grafis, Gramedia, Jakarta, 2001

[5] KBBI/Tim Penyusun pusat Bahasa, ed.3.-cet.3.-Jakarta, balai Pustaka, 2005

[6] Carter, David E., Designing Corporate Identity Programs for Small Corporation, Art Direction Book Company, New York, 1985

[7] Enclopedia Americana Vol.VI, 1976.

[8] Jeffry Scott,Hot To Write For animation,new york,2003

\footnotetext{
*Corresponding author.

E-mail address: menulsukarno@ yahoo.com
} 